\title{
Neurotoxic effects of 2,3,7,8-tetrachlorodibenzo-p-dioxin in cerebellar granule cells
}

\author{
Sun-Young $\mathrm{Kim}^{1}$ and Jae-Ho Yang ${ }^{1,2}$ \\ ${ }^{1}$ Department of Pharmacology \\ School of Medicine, Catholic University of Daegu \\ 3056-6 Daemyeong 4-dong, Nam-gu \\ Daegu, Republic of Korea \\ ${ }^{2}$ Coressponding author: Tel, 82-53-650-4473; \\ Fax, 82-53-626-5694; E-mail, yangjh@cu.ac.kr

\section{Accepted 11 February 2005}

Abbreviations: AhR, aryl hydrocarbon receptor; $\alpha$-NF, $\alpha$-naphthoflavone; $\left[\mathrm{Ca}^{2+}\right]_{1}$, intracellular free calcium; LTP, long-term potentiation; MAPK, mitogen-activated protein kinase; MEK, mitogen-activated protein/extracellular signal-regulated kinase; MK-801, dizocilpine maleate; NMDA, N-methyl-D-aspartate; PDBu, phorbol 12 , 13-dibutyrate; $P K C$, protein kinase $C$; ROS, reactive oxygen species; TCDD, 2,3,7,8-tetrachlorodibenzo-p-dioxin; U0126, 1,4diamino-2,3-dicyano-1,4 bis(2-aminophenylthio)buta-diene

\begin{abstract}
An environmental pollutant, tetrachloro dibenzo dioxin (TCDD) is known to illicit the cognitive disability and motor dysfunction in the developing brain. TCDD induced effects leading to neurodevelopmental and neurobehavioral deficit may have been defined, however underlying molecular mechanism and possible intracellular targets remain to be elucidated. In this study, we attempted to analyze TCDD-induced neurotoxic effects in the granule cells from cerebellum where certain cognitive abilities and motor function command are known to be excuted. [ $\left.{ }^{3} \mathrm{H}\right] \mathrm{PDB} u$, (phorbol 12,13-dibutyrate) binding assay indicated that TCDD induced a dose-dependent increase of total PKC activity and its induction was the aryl hydrocarbon receptor (AhR) dependent and $N$-methyl-D-aspartate receptor (NMDAR) independent. TCDD also caused the translocation of both PKC- $\alpha$ and $-\varepsilon$ in a dosedependent manner but associated with different receptors; PKC- $\alpha$ via AhR but not PKC- $\varepsilon$ indicating an isozyme-specific pattern of the induction. Increase of the ROS formation was also observed in the cells treated with TCDD in a dose-dependent and an AhR-dependent manner. The treatment of the cells with the diamino di-
\end{abstract}

cyano-bis(2-aminophenylthio) butadiene (U0126, MEK-1/2 inhibitor), dizocilpine maleate (MK-801, non-competitive $N$-methyl-D-aspartate glutamate receptor antagonist) and vitamin $E$ attenuated the TCDD-induced ROS production indicating that TCDD-induced ROS formation $m$ ay be associated with activation of ERK-1/2 in the MAP kinase pathway or the NMDA receptor. TCDD also increased $\left[\mathrm{Ca}^{2+}\right]_{1}$, which is associated with ROS formation and PKC activation in the cerebellar granule cells. It is suggested that TCDD activates the NMDA receptor, which may induce a sustained increase of $\left[\mathrm{Ca}^{2+}\right]_{\mathrm{t}}$ in neurons followed by the ROS formation. Our findings may contribute to understanding the mechanism of TCDD-related neurotoxicity, thereby improving the health risk assessment of neurotoxic compounds in humans.

Keywords: cerebellar granule cells; neurotoxicity; PKC; ROS; TCDD

\section{Introduction}

TCDD is an ubiquitous and most notorious environmental pollutant that accumulates in the brain as well as other organs (Kakeyama et al., 2003). Both human and animal studies showed neurotoxic effects of TCDD such as cognitive impairment and motor dysfunctions due to deficit in the neurodevelopmental processes (Legare et al., 2000; Nayyar et al., 2002). Gestational exposure to TCDD in non-human primates showed neurobehavioral and neurodevelopmental deficits in their offspring (Koopman-Esseboom et al., 1994). Recent studies indicated that low-dose exposure to environmental agents, such as dioxin and PCBs during the period of rapid brain growth, known as the "brain growth spurt" in neonatal mice can lead to disruption of the adult brain function, and also to an increased susceptibility to toxic agents at adult ages (Eriksson, $1997 ; 2000)$. These effects are manifested as deranged spontaneous behavior, e.g. hyperactivity, and altered behavioral response to the cholinergic agent, nicotine (Viberg et al., 2002). In addition, these behavioral effects are inducible during a restricted period of neonatal life and get worse with age (Eriksson et al., 2001; 2002). Thus, it is important to identify the window of developmental stage sensitive to the exposure and to understand the underlying mechanism during the brain growth spurt period. Since the previous study indicated that PND-14 is the most vulnerable stage for chemical 
exposure during the development (Yang et al., 2003), cerebellar granule cells in this study were isolated from 7 days old rats and grown in culture for 7 additional days to mimic PND-14 conditions.

One of the most pivotal messenger molecules involved in neuronal function and development is protein kinase $C(P K C)$. PKC signaling pathways have been implicated as an important factor in learning and memory processes (Walaas et al., 1991; Huang and Huang, 1993). Since TCDD is known to alter PKC activities in brain cells (Hanneman et al., 1996), perturbation of PKC signaling pathway may contribute to TCDD-induced neurotoxicities via aberrant PKC-mediated phosphorylation. While activation of PKC is one of the key effects of TCDD, it remains unknown which isozymes are target molecules. Since PKC isozymes are located in different subcellular compartment and have their unique activation profile (Nishizuka, 1988), it is important to analyze the individual PKC isoforms to understand their biological significance in the cellular system.

Reactive oxygen species (ROS) are continuously produced in the cells as byproducts of the electron transport chain in the mitochondria and by increase in $\left[\mathrm{Ca}^{2+}\right]_{1}$ with subsequent activation of several signaling cascades (Mariussen et al., 2002). The developing brain is known to be especially vulnerable to oxidative damage. Thus, it is crucial to understand the effects of TCDD on ROS formation in the developing neuronal cells to better assess the neurotoxic risk.

Therefore, the present study attempted to look into the effects of TCDD on PKC isozymes and ROS production in neuronal cells and identify possible intracellular target molecules for TCDD.

\section{Materials and Methods}

\section{Cerebellar granule cell culture}

Cerebellar granule cell cultures were prepared from the cerebella of 7-day old Sprague-Dawley rat pups as described previously (Yang and Kodavanti, 2001). Cells were plated at $3 \times 10^{6}$ cells/well in 6 -well plate. After plating, cells were incubated at $37^{\circ} \mathrm{C}$ in a humidified incubator with $5 \% \mathrm{CO}_{2}$ atmosphere. Cytosine arabinoside $(5 \mu \mathrm{M})$ was added after $24 \mathrm{~h}$ to prevent growth of non-neuronal cells. Cells were used for the experiments after 7 days in culture. Cultures typically contained $>95 \%$ neurons.

\section{Exposure}

Cerebellar granule cells grown on 6-well culture plates were exposed to $0.01,0.1,1,10 \mathrm{nM}$ TCDD (>99\% purity; KOR, Boston, MA) respectively, for $15 \mathrm{~min}$. In order to get enough proteins for immunoblots, 4 culture plates were used for each concentration. After the exposure, cultures were washed twice with Locke's buffer and the cells were harvested in a final volume of $2 \mathrm{ml}$ buffer $\mathrm{A}$ (described below).

\section{$\left[{ }^{3} \mathrm{H}\right] \mathrm{PDB} u$ binding assay}

Cerebellar granule cells grown on 12-well plastic trays (Costar) were tested at 7 days in culture. ${ }^{3} \mathrm{H}$ ]phorbol ester binding method was adopted from Vaccarino et al. Briefly, the monolayers were washed with Locke's buffer $(154 \mathrm{mM} \mathrm{NaCl} ; 5.6 \mathrm{mM} \mathrm{KCl} ; 3.6 \mathrm{mM} \mathrm{NaHCO}$; $2.3 \mathrm{mM} \mathrm{CaCl}$; $5.6 \mathrm{mM}$ D-glucose; $5 \mathrm{mM}$ Hepes, $\mathrm{pH}$ 7.4) containing $0.1 \%$ fatty acid-free BSA. Following washing, the cells were incubated in Locke's buffer containing $1 \mathrm{nM} 4-\beta-\left[{ }^{3} \mathrm{H}\right]$ phorbol 12,13 -dibutyrate $\left({ }^{3} \mathrm{H}\right] \mathrm{PDBu}$; $0.1 \mu \mathrm{Ci} / \mathrm{ml}$ ) for $15 \mathrm{~min}$ at room temperature with TCDD. An equal amount of DMSO was added to controls. After incubation, the medium was aspirated, and cells were washed three times with Locke's buffer and suspended with $1 \mathrm{ml}$ of $0.1 \mathrm{M} \mathrm{NaOH}$. An aliquot of this sample $(0.7 \mathrm{ml})$ was added to $9 \mathrm{ml}$ Ultima Gold (Packard Inst. Co., Meriden, CT) and the radioactivity was determined using scintillation spectroscopy (Beckman LS 6000LL). A small aliquot was used for protein determination (Bradford, 1976). Nonspecific binding was determined in the presence of $1.6 \mu \mathrm{M}$ phorbol myristate acetate, which was always $<20 \%$, and subtracted from all the values. The unit of $\left[{ }^{3} \mathrm{H}\right] \mathrm{PDBu}$ binding was $\mathrm{fmol} / \mathrm{mg}$ protein/15 $\mathrm{min}$.

\section{Cell fractionation}

Cells were scraped off into buffer A $(20 \mathrm{mM}$ Tris- $\mathrm{HCl}$. $\mathrm{pH} 7.5$, containing $0.25 \mathrm{M}$ sucrose, $2 \mathrm{mM}$ EGTA, $2 \mathrm{mM}$ EDTA and cocktail of protease inhibitors including 0.5 $\mathrm{mM}$ PMSF, $10 \mu \mathrm{g} / \mathrm{ml}$ leupeptin and $10 \mu \mathrm{g} / \mathrm{ml}$ pepstatin). The cells were briefly sonicated and centrifuged at $100,000 \mathrm{~g}$ for $1 \mathrm{~h}$. The supernatants were designated as cytosolic fraction. The membrane proteins in the pellets were extracted with buffer $\mathrm{B}(20 \mathrm{mM}$ Tris $-\mathrm{HCl}$, $\mathrm{pH} 7.5$, containing $1 \%$ Nonidet $\mathrm{P}-40,150 \mathrm{mM} \mathrm{NaCl}$, $1 \mathrm{mM}$ EGTA, $1 \mathrm{mM}$ EDTA and protease inhibitors) on ice for $30 \mathrm{~min}$ followed by centrifugation at $15,000 \mathrm{~g}$ and the supernatants were saved as detergent-solublemembrane fraction.

\section{Immunoblotting for PKC isozymes}

Immunoblot analysis was performed as described previously (Yang et al., 1999). Proteins $(10 \mu \mathrm{g})$ from cytosolic and membrane fractions were separated by $7.5 \%$ SDS-PAGE and transferred to nitrocellulose membrane by Semi-Dry Transfer Cell (Bio-Rad, Hercules, $\mathrm{CA})$. The nitrocellulose sheet was blocked with $5 \%$ non-fat dry milk in Tris-buffered saline. PKC isozymes were detected with isozyme-specific monoclonal antibodies for PKC- $\alpha$ and $-\varepsilon$ isozymes (Transduction Lab, Lexington, $K Y$ ). The blots were reacted with a peroxidase-conjugated anti-mouse $\lg G$ and detected by the Super Signal (Pierce, Rockford, IL). The density of respective bands was analyzed by the Fluor-S (Bio-Rad, Hercules, CA). The data were represented as \% controls.

\section{ROS detection}

Formation of ROS was elucidated by use of the fluo- 
rescent probe DCFH-DA. The detection method was adopted from Mariussen et al. Briefly, the cells were preincubated with DCFH-DA $(5 \mu \mathrm{M})$, dissolved in methanol, at $37^{\circ} \mathrm{C}$ in $5 \% \mathrm{CO}_{2}$ atmosphere for $20 \mathrm{~min}$. $\mathrm{DCFH}$ readily reacts with $\mathrm{ROS}$ such as peroxynitrite (ONOO-) and lipid peroxides to the fluorescent DCF. The medium with the DCFH-DA was then removed, and the cells were added to $1.5 \mathrm{ml}$ prewarmed Hepesbuffered $(20 \mathrm{mM})$ HBSS ( $\mathrm{pH} 7.4)$ with $5 \mathrm{mM}$ glucose containing TCDD. The dishes were incubated for 15 $\mathrm{min}$ at room temperature. Thereafter, the cells were gently removed from the dishes and transferred in triplicate to $250-\mu$ l wells (microtiter plate, 96 wells) for ROS measurement. The formation of the fluorescent oxidized derivative of DCFH, namely DCF (fluorescent at $530 \mathrm{~nm}$ ), was monitored with a luminescence spectrometer (LB96V, Berthold) at $37^{\circ} \mathrm{C}$ for $180 \mathrm{~min}$.

\section{Measurement of intracellular free calcium $\left[\mathrm{Ca}^{2+}\right]_{\imath}$ in cerebellar granule cells}

$\left[\mathrm{Ca}^{2+}\right]_{1}$ was measured in a plate reader using the fluorescent $\mathrm{Ca}^{2+}$-sensitive probe fura-2/AM. The cells were cultured in chambers on coverslips. The cells preincubated with fura-2/AM were treated with TCDD in standard saline solution. Excitations were obtained from filters at $340 \mathrm{~nm}$ and $380 \mathrm{~nm}$ and emission was at 510 $\mathrm{nm}$. $\left[\mathrm{Ca}^{2+}\right]$, was estimated using the equation previously described (Lipton and Nicotera, 1998).

\section{Statistics}

The data were analyzed by one way analysis of variance followed by Tukey's multiple comparison test. The significance was set at $P<0.05$.

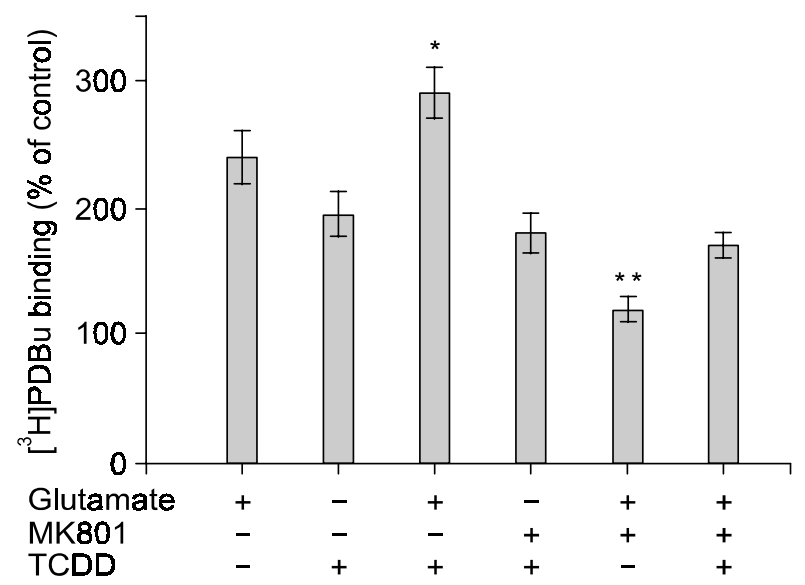

Figure 1. Effects of TCDD and/or MK801 on glutamate-stimulated $\left[{ }^{3} \mathrm{H}\right]$ phorbol ester binding in cerebellar granule cells. Values are mean \pm SD of four preparations. *significantly different from glutamate or TCDD. **significantly different from TCDD.

\section{Results}

\section{Effects of TCDD on PKC}

To determine a total PKC activity following TCDD exposure, $\left[{ }^{3} \mathrm{H}\right] \mathrm{PDBu}$ binding assay was performed. TCDD induced a dose-dependent increase of $\left[{ }^{3} \mathrm{H}\right] \mathrm{PDBu}$ binding. The increase was significant from $1 \mathrm{nM}$ with a maximum of 2 fold increase at $10 \mathrm{nM}$. However, $\alpha$ naphthoflavone ( $\alpha-N F)$, an AhR blocker, inhibited the increase, indicating that the induction was AhR-dependent (Table 1). Subsequent experiments analyzed the effects of TCDD on $\left[{ }^{3} \mathrm{H}\right] \mathrm{PDBu}$ binding in absence or presence of MK-801, a non-competitive NMDA antagonist. While the effects of TCDD and glutamate appeared to be additive, MK-801 did not interfere with TCDD-induced increase of the binding. It is suggested that TCDD effects on $\left[{ }^{3} \mathrm{H}\right] \mathrm{PDBu}$ binding are not mediated via the NMDA receptor (Figure 1).

\section{Subcellular changes in PKC isozymes}

To examine effects of TCDD on PKC isozymes, immunoblot analysis was performed. The cells were fractionated and subsequently immunoblotted against the PKC $-\alpha$ and $-\varepsilon$ monoclonal antibodies. When $1 \mathrm{nM}$ and $10 \mathrm{nM}$ TCDD were exposed, translocations of PKC- $\alpha$ and $-\varepsilon$ isozymes were observed in a dose-dependent manner (Figures $2 \mathrm{~A}$ and $2 \mathrm{~B}$ ). When cells were pretreated with $\alpha-N F$ or/and verapamil, the translocation of PKC- $\alpha$ was blocked by $\alpha$-NF only (Figure 3A). However, the translocation PKC- $\varepsilon$ was not affected by either $\alpha-N F$ or verapamil (Figure $3 \mathrm{~B}$ ). The results suggest that the translocation of $\mathrm{PKC}-\alpha$ and $-\varepsilon$ is mediated via the AhR-dependent and the AhR-independent pathways, respectively, and that TCDD does not directly activate verapamil-sensitive calcium channels.

Table 1. $\left.{ }^{3} \mathrm{H}\right]$ PDBu binding in cerebellar granule cells following TCDD exposure for $15 \mathrm{~min}$ in presence or absence of $\alpha-\mathrm{NF}$.

\begin{tabular}{lrrrr}
\hline & 0.01 & 0.1 & 1 & $10(\mathrm{nM})$ \\
\hline TCDD only & $98 \pm 12$ & $135 \pm 18$ & $164 \pm 11^{*}$ & $190 \pm 15^{*}$ \\
TCDD $(\mathrm{nM})+$ & & & & \\
$\alpha-\mathrm{NF}(10 \mu \mathrm{M})$ & $101 \pm 5$ & $115 \pm 14$ & $121 \pm 18$ & $135 \pm 29$ \\
\hline
\end{tabular}

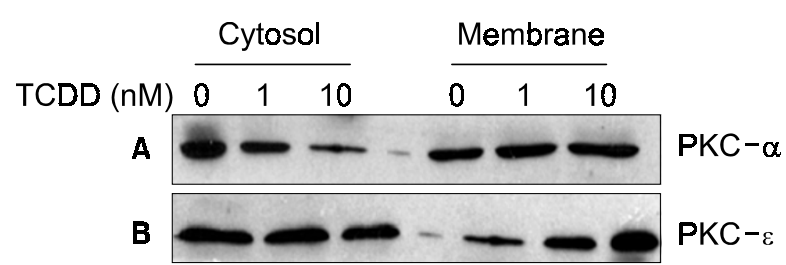

Figure 2. Effects of TCDD on subcellular distribution of PKC- $\alpha$ (A) and PKC- $\varepsilon$ (B) following 15min exposure. Representative profiles of immunoblots from four separate experiments were given. 

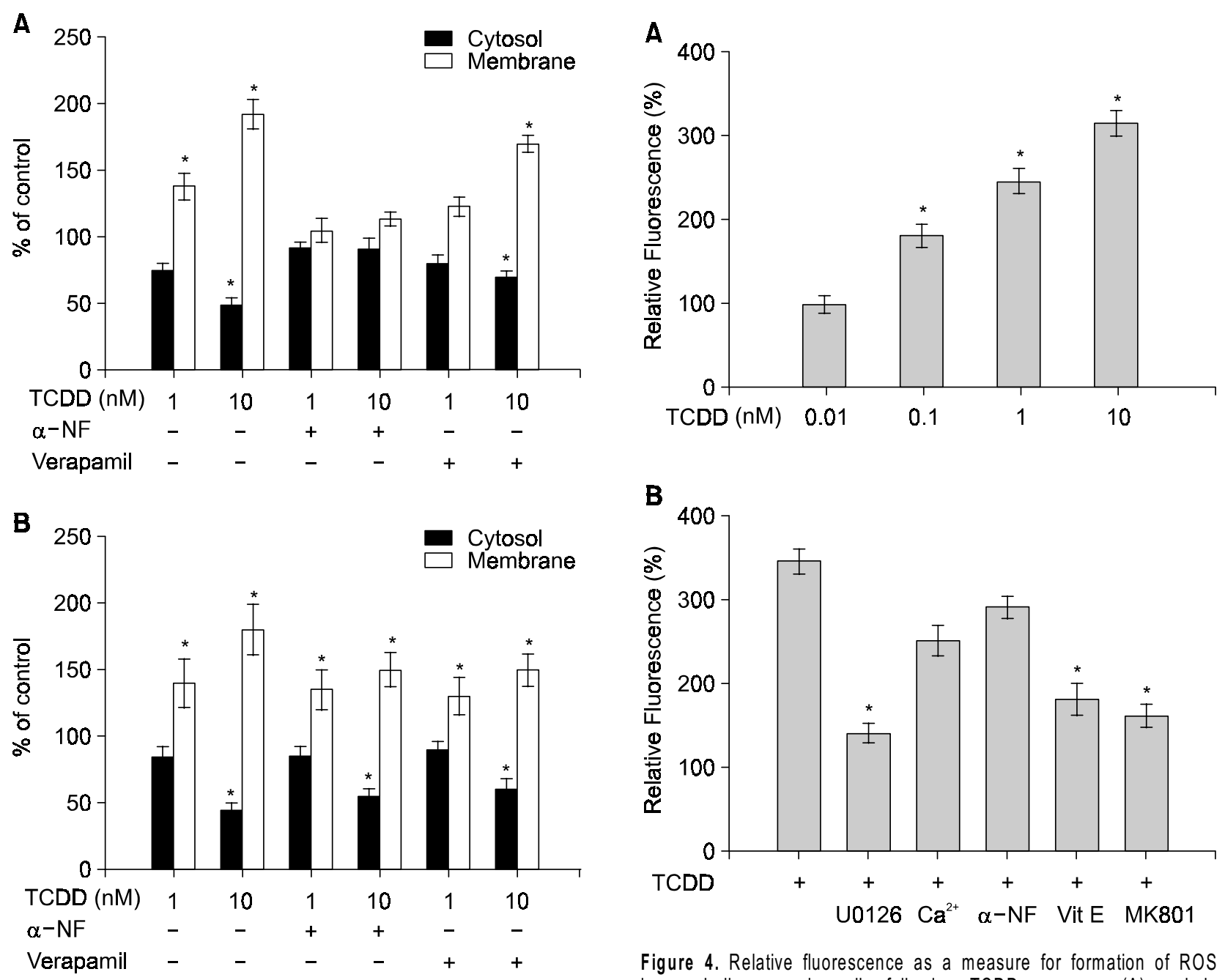

Figure 3. Effects of TCDD on subcellular distribution of PKC- $\alpha$ (A) and $P K C-\varepsilon(B)$ in $S D$ rat cerebellar granule cells in presense of $\alpha$-naphthoflavone $(\alpha-N F)$ or Verapamil.

\section{Effects of TCDD on ROS production}

TCDD showed a dose-dependent increase in ROS production (Figure 4A). A significant production of ROS was detected from $0.1 \mathrm{nM}$ TCDD with the maximum of 3 fold increase at $10 \mathrm{nM}$. Increased production was dampened with the treatment of various protective compounds (Figure 4B). Blockage of the TCDD-induced ROS production was most significant by U0126, a MEK-1/2 inhibitor, and followed by MK-801 and vitamin E. The absence of extracellular free calcium seemed to affect the production in a moderate way. However, $\alpha-\mathrm{NF}$ did not seem to affect the production, suggesting that the ROS production may be AhR-independent.

\section{Changes in intracellular calcium concentrations}

Since increased $\left[\mathrm{Ca}^{2+}\right]_{2}$ may be involved in formation of reactive oxygen species (Berridge and Bootman, 2000), intracellular calcium levels following TCDD ex-

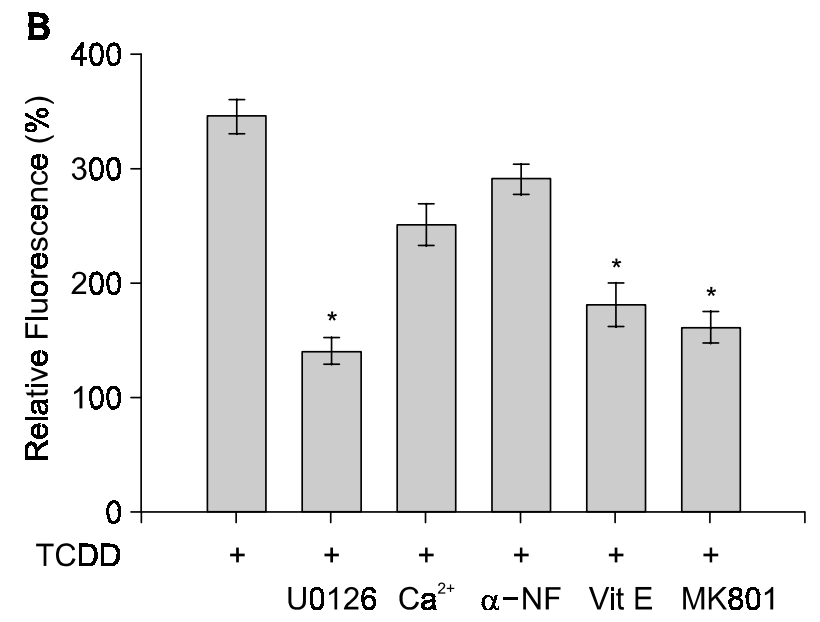

Figure 4. Relative fluorescence as a measure for formation of ROS in cerebellar granule cells following TCDD exposure $(A)$ and in combination with $\mathrm{U} 0126$, calcium-free medium, $\alpha-\mathrm{NF}$, vitamin $\mathrm{E}$ and MK 801 (B).

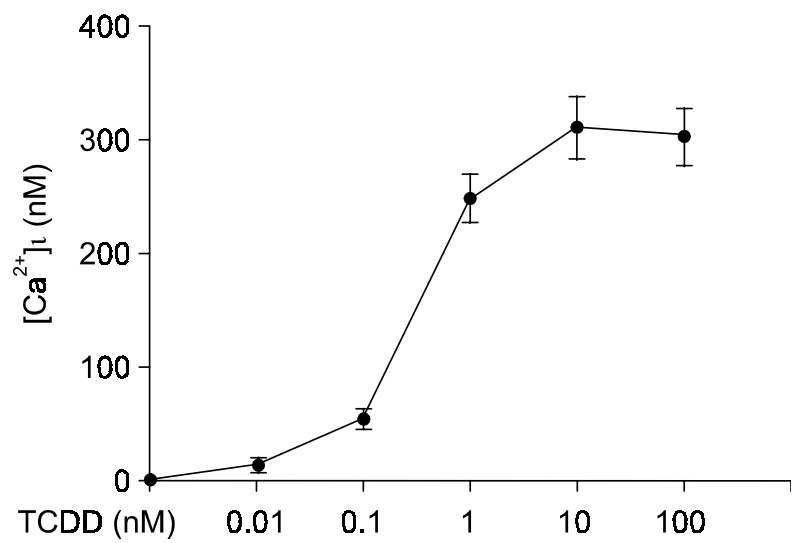

Figure 5. Increase of intracellular calcium concentration after $15 \mathrm{~min}$ exposure to the respective TCDD doses. Four separate experiments were carried out for each concentration. 
posure were measured. It showed that TCDD induced a dose-dependent increase in $\left[\mathrm{Ca}^{2+}\right]_{1}$ in cerebellar granule cells (Figure 5).

\section{Discussion}

PKCs are abundant in neuronal tissue and are involved in neuronal survival and functions of neuronal trophic factors, suggesting a crucial role for PKC in the signal transduction between neurons and the etiology of the neuronal diseases (Matsushima et al., 1996). Since functional roles and subcelluar distributions of individual PKC isozymes are isozyme-specific (Nishizuka, 1988), identification of specific isozymes targeted for TCDD is required to understand the role of PKC in the TCDDinduced neurotoxicity.

$\left[{ }^{3} \mathrm{H}\right] \mathrm{PDBu}$ binding assay indicated that TCDD activates PKC in cerebellar granule cells in an AhR-dependent fashion. It provided the evidence that TCDD interferes with the PKC signaling pathways. It is reported that the induction of $\left[{ }^{3} \mathrm{H}\right] \mathrm{PDBu}$ binding in neuronal cells following the $\mathrm{PCB}$ exposures requires the presence of extracellular calcium (Kodavanti et al., 1994). Since extracellular calcium is an important factor on $\left[{ }^{3} \mathrm{H}\right] \mathrm{PDBu}$ binding in the cerebellar granule cells, we examined a potential route of calcium influx via the NMDA receptor, which is known to mediate calcium entry. MK-801 blocked the effects of glutamate on $\left[{ }^{3} \mathrm{H}\right] \mathrm{PDBu}$ binding, but was ineffective against TCDDinduced increase (Figure 1). The results indicate that TCDD and glutamate may act by the separate mechanism and the NMDA receptor may not be directly involved in the calcium influx required for $\left[{ }^{3} \mathrm{H}\right] \mathrm{PDBu}$ binding.

Immunoblot analysis revealed that translocations of PKC- $\alpha$ from cytosol to memebrane fractions were increased in a dose-dependent manner. PKC- $\alpha$ is selectively associated with lithium-induced memory impairments (Manji et al., 1993). Translocation of PKC- $\alpha$ has been associated with long-term potentiation (LTP) in a hippocampus region (Son et al., 1996). A significant translocation of PKC- $\alpha$ in this study suggests that this particular isozyme may be involved in the TCDD-altered signal transduction pathway. In addition, since PKC- $\alpha$ is $\mathrm{Ca}^{2+}$-dependent isozyme, the translocation may be mediated by the increased free calcium from the exposure of TCDD as shown in Figure 5. However, the treatment of verapamil ruled out the involvement of the voltage-sensitive calcium channel (Figure 3A). Further studies with the additional pharmacological agents are warranted in the future to identify the route of extracellular calcium entry associated with the TCDD-induced PKC activation.

$\mathrm{Ca}^{2+}$-independent forms of PKC are suggested to be involved in the different cellular functions than $\mathrm{Ca}^{2+}$-dependent forms (Konno et al., 1989). Although the physiological roles of $\mathrm{Ca}^{2+}$-independent forms have not been fully clarified, it is known that PKC- $\varepsilon$ is most abundant in the brain and present mainly in the presynaptic component (Saito et al., 1993). This form has been suggested to be a candidate isozyme associated with this presynaptic mechanism of LTP (Herreo et al., 1992). Since PKC- $\varepsilon$ has been associated with a variety of pivotal biological events in neuronal cells, it is feasible that altered subcellular distribution of this particular isozyme may play important roles in the TCDD-induced neurotoxicity. It is of particular interest to note that the translocation of PKC- $\varepsilon$ was not blocked by the AhR blocker, indicating that certain isozymes of PKC may be activated independent of the AhR. Although TCDD is known to affect a total PKC activity, isozyme-specific PKC profiles following the TCDD exposure has not been determined so far. It is believed that this is the first report demonstrating the subcellular changes of PKC isozyme profiles for TCDD exposure. A significant translocation of $P K C-\varepsilon$ in this study further suggests that the TCDD-induced neurochemical changes may be, at least in part, mediated via calcium-independent pathway. Since neurochemical changes following TCDD or neuroactive PCB exposures have been observed only in the presence of extracellular calcium and most of neurochemical events have been considered $\mathrm{Ca}^{2+}$ dependent (Kodavanti et al., 1994), altered subcellular distribution of the $\mathrm{Ca}^{2+}$-independent isozyme in this study may shed a new light in the mechanistic studies of TCDD-induced neurotoxicity.

While the functional roles of PKC- $\alpha$ and $-\varepsilon$ in the cerebellar granule cells are not clear, altered subcellular distribution of these isozymes may cause the disruption of normal signal pathways in the developing brain, which ultimately may lead to motor dysfunction and cognitive deficits. In addition, since these isozymes demonstrated a good dose-response relationship upon TCDD exposure, it is suggested that they may be intracellular target molecules sensitive for the exposure of TCDD and related chemicals.

The involvement of ROS formation in TCDD-induced toxicity was assayed using the fluorescence probe DCFH-DA. This is a sensitive and rapid method, which is well suited for detecting overall oxidative stress after stimulation with ROS-forming compounds in low concentrations (Possel et al., 1997; Myhre et al., 2000). TCDD induced production of ROS in a dose-dependent manner. Vitamin $\mathrm{E}$ decreased the TCDD-mediated increase in ROS production by $48 \%$. This may be attributed to its properties as an antioxidant, making less ROS available for reaction with DCFH (Packer et al., 2001). ROS reduction by vitamin $E$ further confirms the free radicals generated by TCDD exposure.

The NMDA receptor has been associated with glutamate excitotoxicity and free radical formation (Ankarcrona et al., 1995; Lipton and Nicotera, 1998). NMDA receptor activation may induce a fast and sustained increase in intracellular $\mathrm{Ca}^{2+}$ level (Reynolds and Hastings 1995). Since the increase in ROS formation by TCDD was decreased by approximately $54 \%$ with MK-801 and TCDD increased the intracellular $\mathrm{Ca}^{2+}$ levels, it is suggested that TCDD affects the NMDA receptor, which by activation may cause a sustained elevation of the intracellular $\mathrm{Ca}^{2+}$ level in the neuron followed by ROS formation. U0126 also decreased ROS formation by $60 \%$, speculating that activation of 
ERK-1/2 in MAPKinase pathway may be involved. The absence of extracellular calcium seemed to dampen the ROS production, indicating that calcium is an important factor for ROS formation. However, $\alpha-N F$ did not seem to affect the TCDD-induced ROS production, suggesting that ROS formation in cerebellar granule cells may be AhR-independent.

While most of TCDD-mediated biological responses are AhR-dependent, AhR-independent pathways have been suggested in recent studies (Hoffer et al., 1996; Yang and Kodavanti, 2001; Butler, et al., 2004). The ROS production and PKC- $\varepsilon$ translocation by TCDD further support the evidence that the AhR-independent pathways may play pivotal roles in the neuronal cells. Since the health risk assessment of most environmental pollutants is based on the AhR-mediated mechanism of action, whether the responses are AhR-dependent or not is a critical factor in the evaluation of environmental toxic chemicals such dioxins and other structurally related compounds. The compounds that do not show the association with the AhR on their mechanisms of action have been neglected in the risk assessment processes. Our findings clearly demonstrated that ROS formation and $\mathrm{PKC}-\varepsilon$ translocation by TCDD in neuronal cells were independent of the AhR. Therefore, these neuroactive effects are not properly assessed under the current risk evaluation concept. The present study provided a scientific basis that a new concept of risk assessment incorporating the AhR-independent mechanisms of action should be developed to assess the neurotoxic effects of the compounds with more accuracy.

This study revealed that TCDD is directly involved in the alteration of the PKC signaling pathway and the ROS production in neuronal cells, which may contribute to understanding of TCDD-related neurotoxicity. Moreover, identification of intracellular target molecules such as PKC $-\alpha$ and $-\varepsilon$ for TCDD and related compounds may contribute to a better risk assessment of neurotoxicants in humans as well as in our environment.

\section{Acknowledgement}

This work was supported by the Regional Research Center (RRC; Center for marine biotechnology) grant of the Ministry of Commerce, Industry and Energy, Republic of Korea.

\section{References}

Ankarcrona M, Dypbukt JM, Bonfoco E, Zhivotovsky B, Orrenius $S$, Lipton SA and Nicotera $P$. Glutamate-induced neuronal death: Asuccession of necrosis or apoptosis depending on mitochondrial-function. Neuron 1995;15:961-73

Berridge MJ, Lipp P, Bootman MD. The versatility and universality of calcium signalling. Nat Rev Mol Cell Biol 2000; 1:11-21

Butler RA, Kelley ML, Olberding KE, Gardner GR, Van Beneden RJ. Aryl hydrocarbon receptor (AhR)-independent effects of 2,3,7,8-tetrachlorodibenzo-p-dioxin (TCDD) on softshell clam
(Mya arenaria) reproductive tissue. Comp Biochem Physiol C Toxicol Pharmacol 2004;138:375-81

Eriksson P. Developmental neurotoxicity of environmental agents in the neonate. Neurotoxicology 1997;18:719-26

Eriksson $P$, Talts U. Neonatal exposure to neurotoxic pesticides increases adult susceptibility: a review of current findings. Neurotoxicology 2000;21:37-47

Eriksson $\mathrm{P}$, Jakobsson $\mathrm{E}$, Fredriksson A. Brominated flame retardants: a novel class of developmental neurotoxicants in our environment? Environ Health Perspect 2001;109:903-8

Eriksson $\mathrm{P}$, Viberg $\mathrm{H}$, Jakobsson $\mathrm{E}$, Orn $\mathrm{U}$, Fredriksson $\mathrm{A}$. A brominated flame retardant, 2,2',4,4',5-pentabromodiphenyl ether: uptake, retention, and induction of neurobehavioral alterations in mice during a critical phase of neonatal brain development. Toxicol Sci 2002;67:98-103

Hanneman WH, Legare ME, Barhoumi R, Burghardt RC, Safe S, Tiffany-Castiglioni E. Stimulation of calcium uptake in cultured rat hippocampal neurons by 2,3,7,8-tetrachlorodibenzo-p-dioxin. Toxicology 1996;112:19-28

Herreo I, Miras-Portugal MT, Sanshez-prieto J. Positive feedback of glutamate exocytosis by metabotrophic presynaptic receptor stimulation. Nature 1992;360:163-6

Hoffer A, Chang CY, Puga A. Dioxin induces transcription of fos and jun genes by Ah receptor-dependent and -independent pathways. Toxicol Appl Pharmacol 1996;141:238-47

Huang KP, Huang FL. How is protein kinase $C$ activated in CNS. Neurochem Int 1993;22:417-33

Kakeyama M, Sone H, Miyabara Y, Tohyama C. Perinatal exposure to 2,3,7,8-tetrachlorodibenzo-p-dioxin alters activity dependent expression of BDNF mRNA in the neocortex and male rat sexual behavior in adulthood. Neurotoxicology 2003; 24:207-17

Kodavanti PRS, Shafer TJ, Ward TR, Mundy WR, Freundrich $T$, Harry GJ, Tilson HA. Differential effects of polychlorinated biphenyl congeners on phosphoinositide hydrolysis and protein kinase $C$ translocation in rat cerebellar granule cells. Brain Res 1994;662:75-82

Konno Y, Ohno S, Akita Y, Kawasaki H, Suzuki S. Enzymatic properties of a novel phorbol ester receptor/ protein kinase nPKC. J Biochem (Tokyo) 1989;106:673-8

Koopman-Esseboom C, Morse DC, Weisglas-Kuperus N, Lutkeschipholt IJ, Van der Paauw CG, Tuinstra LG, Brouwer A, Sauer PJ. Effects of dioxins and polychlorinated biphenyls on thyroid hormone status of pregnant women and their infants. Pediatr Res 1994;36:468-73

Legare ME, Hanneman WH, Barhoumi R, Burghardt RC, Tiffany-Castiglioni E. 2,3,7,8-Tetrachlorodibenzo-p-dioxin alters hippocampal astroglia-neuronal gap junctional communication. Neurotoxicology 2000;21:1109-16

Lipton SA, Nicotera P. Exitotoxicity, free radicals, necrosis, and apoptosis. Neuroscientist 1998;4:345-52

Manji HK, Etcheberrigaray R, Chen G, Olds JL. Lithium decreases membrane-associated protein kinase $C$ in hippocampus: Sensitivity for the alpha isozyme. J Neurochem 1993;61:2303-10 
Mariussen E, Myhre O, Reistad T, Fonnum F. The polychlorinated Biphenyl Mixture Aroclor 1254 induces death of rat cerevellar granule cells: The involvement of the $N$-methyl$\mathrm{D}$-aspartate receptor and reactive oxygen species. Toxicol Appl Pharmacol 2002;179:137-44

Matsushima $H$, Shimohama S, Chachin M, Taniguchi T, Kimura J. $\mathrm{Ca}^{2+}$-dependent and $\mathrm{Ca}^{2+}$-independent protein Kinase $C$ changes in the brain of patients with Alzheimer's disease. J Neurochem 1996;67:317-23

Myhre O, Vestad TA, Sagstuen E, Aarnes H, Fonnum F. The effects of aliphatic (n-nonane), naphtenic (1,2,4-trimethylcyclohexane) and aromatic (1,2,4-trimethylbenzene) hydrocarbons on respiratory burst in human neutrophil granulocytes. Toxicol Appl Pharmacol 2000;167:222-30

Nayyar T, Zawia NH, Hood DB. Transplacental effects of 2,3,7,8-tetrachlorodibenzo- $p$-dioxin on the temporal modulation of Sp1 DNA binding in the developing cerebral cortex and cerebellum. Exp Toxicol Pathol 2002;53:461-8

Nishizuka $Y$. The molecular heterogenicity of protein kinase $C$ and its implication in cellular regulation. Nature 1988;334: 661-5

Packer L, Weber SU, Rimbach G. Molecular aspects of alpha-tocotrienol antioxidant action and cell signalling. J Nutr 2001;131:369-73

Possel H, Noack H, Augustin W, Keilhoff G, Wolf G. 2,7Dihydrodichlorofluorescein diacetate as a fluorescent marker for peroxynitrite formation. FEBS Lett 1997;416:175-8

Reynolds IJ, Hastings TG. Glutamate induces the production of reactive oxygen species in cultured forebrain neurons following NMDA receptor activation. J Neurosci 1995;15: 3318-27

Saito N, Itouji A, Totani Y, Osawa I, Koide H, Fujisawa N, Ogita K, Tanaka C. Cellular and intracellular localization of epsilon-subspecies of protein kinase $C$ in the rat brain: presynaptic localization of the epsilon-subspecies. Brain Res 1993;607:214-48

Son $\mathrm{H}$, Madelian V, Carpenter DO. The translocation and involvement of protein kinase $C$ in mossy fiber-CA3 long-term potentiation in hippocampus of the rat brain. Brain Res 1996; 739:282-92

Viberg $H$, Fredriksson A, Eriksson P. Neonatal exposure to the brominated flame retardant 2,2',4,4',5-pentabromodiphen$\mathrm{yl}$ ether causes altered susceptibility in the cholinergic transmitter system in the adult mouse. Toxicol Sci 2002;67:104-7

Walaas SI, Greengard P. Protein phosphorylation and neuronal function. pharmacol Res 1991;43:299-349

Yang $\mathrm{JH}$, Vogel $\mathrm{C}$, Abel J. A malignant transformation of human cells by $2,3,7,8$-tetrachlorodibenzo-p-dioxin exhibits altered expressions of growth regulatory factors. Carcinogenesis 1999;21:5-12

Yang JH, Kodavanti PRS. Possible molecular targets of halogenated aromatic hydrocarbons in neuronal cells. Biochem Biophys Res Commun 2001;280:1372-7

Yang JH, Derr-Yellin EC, Kodavanti PRS. Alterations in brain protein kinase $\mathrm{C}$ isoforms following developmental exposure to a polychlorinated biphenyl mixture. Mol Brain Res 2003; 111:123-35 